\section{UNIVERSITIES AND THE STATE.}

THE deputation which was received by the Prime Minister on Friday last put forward a plea for the State endowment of , universities which has been accepted by leading nations as a fundamental principle of progress. The influence of this principle upon the development of nations was shown by Sir Norman Lockyer in his address to the British Association last year, and the deputation was organised by the Association as the natural outcome of this address.

It would scarcely have been possible for a case to have received more impressive support than was given to it by the representatives of universities, industries, national and local interests who responded to the appeal issued by the British Association as to the need for recognition of the responsibility of the State for higher education and research. Of the four hundred people who expressed the sympathy of the bodies or organisations they represented with the manifesto sent out by the Association, only two hundred could be received by the Prime Minister, but these included leaders in many departments of national activity.

In introducing the deputation, the importance of the State endowment of universities was urged by Sir Norman Lockyer, as presented in his address. That university authorities hold the same view as the men of science and political leaders was shown by Prof. Pelham, representing Oxford; the Vice-Chancellor of Cambridge; and Mr. Chamberlain, who spoke for the new universities. The importance of applications of science was represented by $\operatorname{Sir} W . H$. White and Sir W. Ramsay; the importance of the humanities by Sir R. Jebb; and the importance of research by Sir Henry Roscoe. Mr. A. Moseley spoke on American science and industry, and Mr. Bell, M.P., speaking in the absence of Mr. Burt, M.P., pointed out the importance of the reduction of fees and complete educational organisation, and showed by his presence that the State endowment of universities is approved by the artisan classes of the country.

In replying to the deputation, $\mathrm{Mr}$. Balfour acknowledged that the endowment of universities assisted a nation in the industrial struggle, and that there is a great need, both in the new and the old universities, for help toward this object. The Chancellor of the Exchequer said that he would double the grant for university colleges this year, and he hoped to be able to redouble it next year; but before considering any larger contributions to university education he would like an exposition from the universities themselves as to the extent they were prepared to come under control if they received grants. He referred to the additional grant of $75,000 l$. a year to university colleges (representing a capital sum of $3,000,000 l$. at $2 \frac{1}{2}$ per cent.) as having already been given as the result of the appeal made last year by the president of the British Association. From this it seems quite clear that if the university colleges had been content to wait until the general appeal was made, the result might have been better all round-so far as the early grant of money is concerneu.

As the general result of the deputation, we may therefore take it that the principle of State endowment of universities has been conceded, and that the Government is prepared to deal with the question in a liberal manner when the universities have expressed their views as to control, and the finances of the cointry permit large contributions to be made.

The manifesto issued by the British Association was as follows :-

$$
\text { NO. I } 8 \text { I } 2 \text {, VOL. 70? }
$$

Statement prepared by the president of the British Association and revised by a committee consisting of the Deputy Vice-Chancellor of the University of Oxford, the Vice-Chancellor of the University of Cambridge, Sir Oliver Lodge, principal of the University of Birmingham, Sir Michael Foster, M.P., and Sir Henry Roscoe.

\section{The National. Need of the State Endowment} OF UNIVERSITIES.

(I) The British Association has taken action regarding the State endowment of universities, because at the present juncture the highest education and research is a matter not merely of academic but of the gravest national concern.

There is now a general opinion that Britain is in danger of falling behind in the industrial competition now going on between the most highly civilised States.

The university no less than the primary school is in question, because we are in the midst of a struggle in which science and brains take the place of swords and sinews; the school, the university, the laboratory and the workshop are the battlefields of this new struggle, and the scientific spirit must not be limited to the workshop, since other nations utilise it in all branches of their administration and executive.

The more our legislators, administrators and executive officers possess the scientific spirit, and the more the rule of thumb is replaced by scientific methods, the more able shall we be to compete successfully with other countries along all lines of national as well as of commercial activity.

It is a question of an important change of front, of finding a new basis of stability for the Empire in face of new conditions; and since the full life of a nation with a constantly increasing complexity, not only of industrial but of high national aims, depends upon the universal presence of the scientific spirit, of brain-power, our whole national life is involved.

The Function of a University in a Modern State.

The men upon whom the nation must chiefly depend for aid under the complex conditions of the modern world must not be entirely untrained in the study of the nature and causes of the things which surround them, or of the forces which have to be utilised in our daily life; their training and education in humanities must also have been of the widest.

Such men cannot be produced either by a university which neglects science or by a technical college which neglects the humanities.

Hence the universities must be enabled to combine these two sides of a complete education, and they must also be enabled to foster research along both lines, for research is the highest and most important instrument of education, as well as its most valuable result. When science and its applications were of less importance than now the humanities sufficed and university requirements were small; rooms, books, and a small number of teachers of a small number of subjects comprised the essentials of the university. Modern university needs have been too much regarded from this old standpoint.

All this is now changed. For instance, in the most modern German university the buildings, all elaborate and all differing from each other, have already cost a million, and still the university is not complete. Books have to be supplemented by expensive instrumental equipments, which constantly have to be added to or replaced, and by utilising this new material the fruitful ramifications of learning have increased fifty-fold, and the teachers naturally in even greater proportion.

The extraordinary thing is not that a claim to meet 
these new conditions is made now, but that we have waited so long for it in this country while other countries faced them long ago.

\section{The Money.}

Money is required at the present moment for :-

(I) Buildings and equipments for pure and applied science in both old and new universities.

(2) Pay and pensions of an increased number of professors, demonstrators, \&c., in pure and applied science in both old and new universities.

(3) Strengthening of science teaching and research in all, and of the humanities in the new universities.

(4) Reduction of fees, and the wide educational enfranchisement of proved ability in all classes.

Hitherto universities have looked mainly to private endowments. Universities have been regarded too much as luxuries of the rich, and perhaps on this ground higher education has been treated by the Government as of trivial importance to the nation, as a thing it may properly disregard.

Judging from the action taken in other countries, it is safe to say that private endowment has not produced more than ro per cent. of the money actually needed in Britain.

Nor can we rightly appeal to local rate-aid alone. It would be unjust to expect certain restricted localities to provide universities which, if we are to go on, must be utilised by the whole Empire.

We are driven then to the State. The other civilised States largely endow their universities; Germany, with an aggregate income less than ours, spends roughly a million a year on its universities. The University of Berlin alone received more than 168 ,oool. from the State in the year I89I-2. In the United States, in addition to $200,000 l$. a year received from the Government, the States supply 70o,oool. in the aggregate and private endowment 2,00o,oool. The University of Tokio receives $130,000 l$. a year from the Government of Japan.

These figures derive their chief importance from the fact that these magnificently endowed and State-aided universities are the institutions we are contending with in the production of men to do the nation's work along all the lines of its activities.

But the large sums available for the efficient working of the German and American universities are not alone in question. The number of universities in Germany is nearly double that of the British universities. The number of first-class universities in the United States, where, as Mr. Choate has told us, education is the chief business of the nation, is nearly four times that of the British universities.

Can we Afford to Spend Money on Universities?

Britain's great needs at the present moment are brain-power to invigorate our commerce, among other things, and sea-power to guard it, among other things. The State has recently spent $120,000,000 l$. to bring our Navy up to date; it has not yet spent a single million on our universities.

Sir Robert Giffen has stated that the yearly income of the people of the United Kingdom may be taken as not less than $165^{\circ}$ millions, and their aggregate expenditure a few years ago was not less than $\mathrm{r}, 400,000,000 \mathrm{l}$, including $30,000,000 \mathrm{l}$. for education, which is less than 2 per cent. of the whole. The amount borne on the estimates for education is about I3, 000, 000l.

He writes:- "The country should be spending Ioo millions where it now spends 30 , or about 5 per cent. ... Such sums are not really extravagant. Extensive diffusion of education and scientific knowledge and training are not only essential to the greater efficiency of labour and capital by which the means of living are provided, but they are equally needed for the conduct of life itself, for the health and comfort of the workers."

It cannot be doubted that the expenditure will be quickly remunerative. More efficient workers will produce more.

Money so spent is seed from which a harvest can be looked for; the plentifulness of the crop will depend upon the seed and the way it is sown.

One of our manufacturers who has been most successful in applying science to industry has stated that if we were now to borrow $10,000,000 l$. for university purposes we should get the money back in the course of one generation a hundred-fold.

The recent recognition of the fact that we have too few universities, and that those that we have are inefficient for want of funds, is similar to that awakening which occurred in 1888 regarding the Navy. In both cases we have to correct past mistakes lasting for years, and seeing that university buildings, as well as annual endowments, are required, some special provision should be made for their early erection.

\section{The Universities in Relation to Secondary Education.}

Now that the primary and secondary schools throughout the country are being coordinated, the time has arrived for making our universities and university colleges efficient. The teaching connected with the universities must be of the highest, and the chief function of the secondary schools should be to produce students possessing that general training in science and the humanities which will ensure the success of their subsequent careers, either inside or outside a university.

A system of leaving certificates and a reduction of fees would at once get rid of the tyranny of merely qualifying or selecting examinations which are the bane of education, and would enable the training of the poorest to be carried to the highest rung of an unbroken ladder.

The deputation which advocated these views included representatives from the universities and university colleges, and from county, municipal and other educational authorities in Great Britain and Ireland, Canada and Australia. The list of the deputation contained the names of some who intended to be present, but were prevented from attending. Lord Rosebery, for instance, was unable to attend as Chancellor of the University of London; but with the exception of Oxford, Cambridge, and London, the chancellors of all the universities appear to have formed part of the deputation. A very large number of members of Parliament were present; and it is not too much to say that every important body of opinion-social, industrial, and intellectual-was represented. Among the members of the deputation were the following:-

The Vice-Chancellor of Oxford University, the president of Magdalen College, the president of Trinity College, Prof. Poulton, Prof. Miers. The Vice-Chancellor of Cambridge University, Sir R. C. Jebb, M.P., Mr. A. E. Shipley, F.R.S., and Prof. Forsyth, F.R.S.

The Vice-Chancellor (Dr. Pye-Smith) of London University, Sir Edward Busk, Sir Arthur Rücker, Sir Henry Roscoe, and Prof. Unwin. Sir John Aird, Bart., M.P., Sir G. C. T. Bartley, K.C.B., M.P., Sir M. M. Bhownaggree, M.P., Lord Hugh Cecil, Mr. W. R. Cremer, M.P., Sir M. Foster, K.C.B., M.P., Mr. Ernest Gray, M.P., and Dr. T. J. Macnamara, M.P. The chairman of the London County Council, and the chairman of the Education Committee of the L.C.C. Masters and wardens of the Fishmongers', Goldsmiths', Skinners',

$$
\text { No. I 8I 2, VOL. 70] }
$$


Merchant Taylors', Ironmongers', and Vintners' Companies. Lord Reay, Hon. W. F. D. Smith, M.P., Lord Edmond Fitzmaurice, M.P., Sir William Hart Dyke, M.P., Mr. James Bryce, M.P., Sir Donald Currie, and Lord Stanley of Alderley. The principal of 'University College (Dr. Carey Foster), the principal of King's College (Dr. Headlam), Lord Macnaghten, the Bishop of London, the Bishop of Rochester, Sir John Wolfe-Barry, K.C.B., F.R.S., Mr.

A. H. D. Acland, and Mrs. James Bryce.

Durham University was represented by Lord Londonderry, Earl Percy, the Bishop of Durham, the Dean of Durham, Principal Gurney, Lord Armstrong, Hon. C. A. Parsons, F.R.S., and Sir E. Grey, Bart.

The Chancellor of Victoria University, Manchester (Earl Spencer, K.G.), the Lord Mayor of Manchester, Sir J. T. Hibbert, K.C.B., Sir William Houldsworth, Bart., M.P. Sir James Fergusson, Bart., M.P., Sir J. Hoy, Sir Frank Forbes Adam, Prof. Schuster, Prof. Dixon.

The Chancellor of Leeds University (Marquis of Ripon, K.G.), Lord Wenlock, chairman East Riding Council; Mr. Herbert Gladstone, M.P.

The Shancellor of Liverpool University (Earl of Derby, K.G.), Prof. Boyce, F.R.S., Sir J. T. Brunner, Bart., M.P.

The Chancellor of Birmingham University (Mr. Chamberlain), Sir Oliver Lodge, Sir A. Hickman, M.P., Lord Cecil Manners, M.P., Sir P. A. Muntz, M.P.

The Bishop of Hereford, president of University College, Bristol; Prof. C. Lloyd Morgan, F.R.S., the Right Hon. Lewis Fry, Sir Frederick Wills, Bart., M.P., and Mr C. E. Hobhouse, M.P. Alderman J. Bright, J.P., chairman of council of University College, Nottingham; Lord Henry Bentinck, M.P., and Sir F. A. Milner, M.P. Mr. J. H. Benyon, president of University College, Reading. The Duke of Norfolk, K.G., president of University College, Sheffield; Sir Fredk. Mappin, Bart., M.P., Dr. Hicks, F.R.S., Sir W. H. Holland, M.P., and Sir Howard Vincent, M.P. The Duke of Wellington, K.G., president of Hartley University College, Southampton; and Lord Northbrook, chairman Hampshire County Council.

The Head Masters' Conference, Rev. Dr. Gow. The Head Masters' Association, Canon Bell, Dr. McClure. The Assistant Masters' Association, the chairman, Mr. G. F. Daniell; vice-chairman, Mr. R. F. Cholmeley; and others.

The British Association for the Advancement of Science, the president, Sir Norman Lockyer, K.C.B., and the treasurer. The Royal Academy of Arts, the president, Sir Edward Poynter, R.A. The Society of Arts, Sir W. de W. Abney, K.C.B., F.R.S. Institution of Civil Engineers, Sir William H. White, K.C.B., F.R.S. Iron and Steel Institute, the president. The Society of Chemical Industry, Sir William Ramsay, K.C.B., F.R.S. Associated Chambers of Commerce, the president. Association of Municipal Corporations, Sir Albert Rollit, M.P. County Councils Association, Sir John T. Hibbert, K.C.B.

The Vice-Chancellor of the University of Wales (Principal Griffiths, F.R.S.), Lord Rendel, Sir Lewis Morris, the Right Hon. Lord Kenyon, Prof. R. W. Phillips, Prof. W. Rhys Roberts, the Lord Lieutenants of many counties, the Right Rev. the Lord Bishop of Llandaff, the Right Rev. the Lord Bishop of St. David's, and the president of the Miners' Federation.

The principal of the University of St. Andrews (Dr. James Donaldson), the president of University College, Dundee (Earl of Camperdown), and Sir John Long, M.P. University of Glasgow, Prof. G. G. Ramsay, Prof. Thomas McCall Anderson, Sir John Stirling Maxwell, Bart., M.P., Sir Herbert E. Maxwell, Bart., M.P. University of Aberdeen, Sir George King, K.C.I.E., F.R.S. University of Edinburgh, the Vice-Chancellor and principal, Sir William Turner, K.C.B.

The Chancellor of the University of Dublin and Trinity College (Earl of Rosse, K.P., F.R.S.), Lord Rathmore, and the provost of Trinity College (Dr. Traill). The ViceChancellor of the Royal University of Ireland (Right Rev. Monsignor Molloy). The president of Queen's College, Belfast (Dr: Hamilton), the Lord Mayor of Belfast. The president of Queen's College, Cork (Sir Rowland Blennerhassett, Bart.). The president of Queen's College, Galway (Dr. Alex. Anderson). The president of University College, Dublin, Catholic University of Dublin (Rev. W. Delany, S.J.).

NO. I 8 I 2, VOL. 70]
Principal Petersen, the McGill University, Montreal. Prof. A. Liversidge, University of Sydney.

Limitations of space will not permit the publication of a complete report in these columns, but the subjoined extracts from the speeches will convey an idea of the points raised. After the deputation had been briefly introduced by Sir Norman Lockyer, Prof. Pelham, speaking on behalf of the Hebdomadal Council of the University of Oxford, said :-

We are here to express our entire sympathy with the main object of this deputation. The older universities welcome this opportunity of standing in line with the newer universities which are growing up around us.

The Vice-Chancellor of the University of Cambridge (Dr. Chase) said :-

The council of the Senate of the University of Cambridge is deeply conscious, as, indeed, everyone must be who looks thoughtfully on the events of the time, how much that higher culture and that thorough scientific study and research which it is the province of a university to promote are needed for the service of the English nation.

It appears to us that the universities, in view of the increasing work which they are doing on behalf of the nation, are justified in asking for the sympathy and the cooperation of the State. We heartily join in the prayer that the Government would be pleased to regard the work of universities as of supreme national and imperial importance, and to give such aid as the several universities need and as wider considerations of national finance render possible.

Mr. Chamberlain, as Chancellor of the University of Birmingham, speaking on behalf of the new universities, said :-

Let me take Birmingham as an example and as a paralle to what is being done in Liverpool, Manchester, Wales, and Leeds. We have had to prepare the plan of a new scientific university, to deal only with that side of our work, at an estimated cost of $1,000,000 l$. sterling. Even then we shall not have fulfilled all our objects, for there will be many branches of higher scientific and practical education for which we have made no sufficient provision. In the case of Birmingham local subscription has produced about $450,000 l$, and on the basis of that subscription we have put in hand what will-amount to little more than one-third of the university requirements. We have called in aid the local rates, and the three counties of which Birmingham is the centre each contribute the sum of $500 \mathrm{l}$. a year, and the corporation of the City of Birmingham has offered in aid a rate of $\frac{1}{2} d$. in the pound, which will produce something between $6000 l$. and $7000 l$. per annum. Now, what ever may have been done, it is not enough, and we recognise that by our own unassisted resources alone we cannot provide the kind of education we believe the country requires. Already the State pays something like 13,00o,oool. a year for primary education. Only a few thousands a year are found for the higher education to which we have learned to attach so great a value. I am not speaking merely as a Chancellor, but I have had some practical experience of the advantage which every statesman finds in discovering sources from which funds may be provided for all the admirable objects brought to his notice, and I do not press on you any particular figure or method of dealing with the important matter we have brought before you, but I hope we may have some crumbs from your table. I hope at least the present Government may be able to make a satisfactory beginning in recognising these new necessities. Possibly that beginning may not be wholly satisfactory to us, but we shall be always ready to take half a loaf until the time comes when we can get the whole, and I believe the initiation of such a policy on the part of any Government will be one of its best claims to the gratitude of the people of this country.

Sir William White, K.C.B., F.R.S., speaking as president of the Institution of Civil Engineers, and 
as a representative of all branches of engineering, said :-

During the past year a committee representing all branches of engineering, and nominated by all the principal engineering societies of the country, has been considering the best system of training for engineers. Its work is still incomplete, but its investigations make it obvious that great extensions of existing universities and university colleges which provide for engineering education are needed in order to meet national requirements and to secure equality of conditions with those existing in other countries where industrial enterprise is making great strides.

British engineers consider that private enterprise and generosity should continue to play a leading part in the support of institutions for teaching the higher branches of their profession, but they hold that, in view of what is being done abroad, it is absolutely necessary that private efforts should be supplemented by substantial Government aid. Such a course on the part of the Government would undoubtedly tend to stimulate private generosity, and before long would place this country in a position of relative efficiency greatly superior to that which now prevails. With the rapid development of engineering now taking place in all directions, there is an absolute necessity for scientific procedure and a thorough knowledge of principles on the part of those employed therein. Unless immediate steps are taken to remedy needs that are universally recognised, the industrial position of this country must become increasingly unsatisfactory.

The importance of the application of science was urged by Sir William Ramsay, K.C.B., who, in the course of his remarks, said :-

In asking for a new departure-the State endowment of universities - we must inquire what information we can obtain from others who have previously made experiments. We find that on the Continent successful experiments have been made for many years. In these practical researches Germany has taken the lead; but in all European countries, and in America, progress is being made on lines closely resembling those which have been found advantageous in Germany. We may note that almost all the proprietors of chemical works, or of works which depend for their success on the application of chemical principles, are either university men who have taken a degree in science or men from "Polytechnika," who have taken a diploma.

One reason for the almost universal spread of university education is the very small fees that are charged to students. By far the larger portion of the cost of university education is paid by the State--probably three-quarters. Ten pounds covers a year's education in fees, whereas forty pounds must be charged here in non-endowed universities.

This close contact between science and industry can be maintained only by a graduated and relatively high scale of pay for the professors in the large universities. Unless the prizes are sufficient to tempt men to choose a schulastic career instead of a commercial one, the ablest young men will choose commerce.

In America most of the chemists have either been educated in Germany-the older generation especially-or have been trained in copies of the German schools of chemistry. Hence America entertains much the same ideas as Germany as regards the importance of scientific training. Indeed, manufacturers engage the services of youths who have not finished their "college" career.

As regards the merits of universities and "Polytechnika," the main difference is that in the former students have been trained in methods of research, whereas in the latter they have been taught what is already known. I am informed by a leading German manufacturer that he prefers the university youths to those trained in "Polytechnika," because the former are more suggestive. The inventive power is recognised as the highest and most lucrative when applied to industry. I am convinced that the bestowing of money on the support of the university teaching of science, while desirable for its own sake, will be like casting bread upon the waters, it will be repaid a hundred-fold.

In referring to the needs of the younger universities in respect to literary studies, Sir Richard Jebb, M.P., remarked :--

$$
\text { NO. I } 812 \text {, VOL. } 70 \text { ] }
$$

It would be a serious national misfortune if our education should become one-sided. The humane studies-history, philosophy, language, literature-cultivate the imagination, enlarge the sympathies, widen the outlook upon life, aid in fitting people to understand one another and to cooperate intelligently; in a word, they are essential elements in the formation of the efficient worker, whatever his line of work may be. That cardinal fact is thoroughly well understood in those countries where education, from the lowest to the highest grade, is best organised. Let us see to it that in our own country we do not overlook this fact. The men of science go heartily, I believe, with the men of letters in desiring that it should not be overlooked. The importance of maintaining such an equipoise in education might be urged on the utilitarian ground, as a condition of our holding our own in the competitions of the civilised world. But it must be urged also on a higher ground, as a thing essential to the intellectual and spiritual well-being of the nation and of the Empire.

Sir Henry Roscoe pointed out the influence of scientific research on our national well-being; and in his speech he said:-

It is to the university that we must mainly look to raise the type of man who by training and character is fitted to prosecute research. Are our British universities at the present moment adequately equipped in men and material to enable them to carry out successfully this national work? A comparison of their capabilities with those of other countries shows a deplorable deficiency in both the above respects.

This state of things being generally admitted, we come before you as the head of the Government to ask you to bring about that closer connection between scientific method, scientific studies, and national industry, upon which you have so strongly insisted, by giving to our universities a State endowment which will not merely serve as a national insurance against attack from without, but is, unlike others, a productive insurance which will repay the nation, not merely once, but over and over again.

Speaking more especially as a business man who has noted the effect of applied science in the industrial world, Mr. A. Moseley, C.B., remarked:-

I am practically impressed with the necessity for those in training for commerce and industry to be thoroughly equipped with technical instruction of university rank, designed to bear especially upon the particular vocations that the rising generation intend entering. On the points mentioned we are distinctly behind both Germany and the United States of America. The success of the United States at present, and perhaps even more so in the future is and will be due to the higher scientific and practical training her young people receive in her universities first and technical colleges afterwards.

Mr. Bell, M.P., speaking in the absence of Mr. Burt as the representative of artisan classes of the country, said :-

This question is one of vital importance. Unfortunately, my practical knowledge of universities is little. But hitherto a university training has been the luxury of the comparatively well-to-do. The aim is to open the door to the choicer spirits of the poorer classes.

Lord Kelvin wrote to the president of the British Association expressing his regret at not being able to be present and his hearty wishes for the success of " every effort for the much-needed improvement and strengthening of the universities of the United Kingdom."

In the course of his reply to the deputation, Mr. Balfour said :-

I do not suppose that there have ever before been congregated in one chamber so many representatives of learning in this country. We have been told that we have fallen far behind at least two great countries in our educational 
facilities. But I do absolutely deny that there is the smallest sign that in the production of these germinating ideas of science we have shown any inferiority, either to our relations across the Atlantic or to Germany, which I may remind the assembly has "for many generations pursued this State-endowing process of applying science to industry. That we are behind Germany in that way I do not deny. Germany had a technical university, or gave technical teaching, I think, as far back-I am refreshing my memoryas the end of the eighteenth century, if not before. Of course, the general system of thought in Germany, the habits of the people and the Government in this respect places them at a great advantage as compared with us as far as the endowment of universities can help a nation, as I doubt not it can, in the industrial struggle. But my point is that mere endowment of universities will not, I think, add greatly to the output of original work of the first quality. What, then, will it do? It will do, or may help to do, what is, perhaps, now more important. will provide an education which will render fit for industria work all persons who, without university education, would be very ill equipped indeed. I concur with all the speakers to-day that there is a great need-a great financial needboth in the new and the old universities for help towards this object. But I would beg to point out that there is even a greater necessity than a well equipped university - that is, that capitalists should be prepared to realise what we realise in this room-the necessity of giving employment to those whom these universities are to turn out. was much struck by an observation of Sir William White's. He pointed out that we passess most of the ships of the world--that we are the largest shipbuilders in the worldand yet he said that Germany has an incomparably larger number of students, far better machinery for educating these students, and more men occupied in the shipbuilding yards; and what Germany has done the United States are doing. One of two things is clear. Either our shipbuilders think this qualified class is necessary or they do not think so; or else they find British students, even though turned out in smaller quantities, are sufficient for their purpose, or they employ American and German students for their works. Are our manufacturers convinced that they get a better man if they get one who has been to a university? Or do they think that if a young fellow wants to become one of the captains of industry he should begin early in life? I think there is some evidence to show that they prefer the older course; and I should suggest they are wrong; and if they are wrong you must convince them they are wrong. otherwise there will be no advantage in turning out qualified students, for they will be content to use the man who acquires his training by actual day-to-day labour on the ship, but is not qualified by these higher scientific attainments which are more and more becoming necessary.

One other thing we want, and that, I think, is the creation of positions which will enable a man who has exceptional gifts of originality in science to devote his life to the subjects of his predilection so as not to be driven to another kind of life in which he will not be able to render the full service of which he is capable to his country. In Germany certainly-I am not sure about the United States - such positions exist to a far greater extent than in this country. In the main they must be attached to the universities. I cannot conceive any more admirable use of any funds which the universities can command than the increase of the number of such positions.

In the course of his remarks, the Chancellor of the Exchequer said :-

It would be of some assistance to those who nay have to decide in future when money is available if the universities would consider to what extent they are willing to come under control if they receive grants, to what extent the State is to have a voice in fixing the fees of the students, to what extent it is to direct or infiuence the teaching, whether it is to allocate its assistance to promote special branches of study, or whether it is desired to make every university complete in itself. Some further exposition of their views would make it easier to deal with this question when the time comes for dealing with it.

NO. I 8 I 2, vOL. 70]

\section{THE MEETING-PLACE OF EAST AND WEST. ${ }^{1}$}

THE publication of Dr. Stein's preliminary report

to the Royal Geographical Society and of his own personal narrative of his explorations among the " sand-buried ruins of Khotan" is one of the most important archæological events of the year 1903. For the full scientific publication of the whole of his discoveries by the Indian Government we must perforce wait awhile, but we have all that is needed to enable us to form a general idea of them in the interesting and well published volume which lies before us.

Chinese Turkestan hardly sounds as if it were a land of very great interest, yet, as a matter of fact, it is historically one of the most interesting countries in the world. It is not a comfortable country : merely a string of oases half overwhelmed by a devouring desert of shifting sands, the great Taklamakan, and barred off from the rest of the world by huge and impassable mountains, scorchingly hot in summer and frozen by Arctic cold in winter. Yet these remote wilds have seen one of the most interesting phenomena of history, the meeting together of the civilisations of China, of India, and of Europe; here the antique cuiture of China had in the eariy days of the Roman Empire already been brought into contact with Græco-Roman civilisation, and we see the result of the meeting of the two, or, including India, three streams of civilisation in the mixed culture of Turkestan in the early centuries of the Christian era, which Dr. Stein has brought to light.

In those days Chinese Turkestan was the bridge between west and east; from west to east journeyed Roman merchants to buy the precious silk of Serica, and Persian ambassadors or fugitive princes passed seeking the assistance of the mighty Emperor of China; from east to west Chinese armies marched through Turkestan into the basins of the Oxus and Jaxartes, and even reached the Caspian, and Chinese pilgrims, like Fa-hien and Hiuen-Thsang, passed the fanes of Khotan on their way to the holy places of Buddhism in India; traffic to and fro was continuous, and the oases of the Taklamakan could maintain many famous cities, rich temples, and monasteries of renown.

In those days of her importance, as still in these of her desolation, eastern Turkestan was under the political hegemony of China. Legends, indeed, ascribe a remote date B.c. to the first entry of the Chinese into Kashgaria, but since real history (as apart from annals which have not yet been critically sifted) can hardly be said to begin for China before the reign of the great reformer Tsin Chi-Hwangti (B.C. 250), "the burner of the books," we are probably right in assigning the first Chinese occupation to the early days of the Han dynasty, under the emperor Han Wu-ti (B.c. IOo), and its first real conquest to the famous General Panchao, who is said to have carried the Chinese arms as far west as the Caspian, and to have attempted to open up direct relations with the Romans (about A.D. I0o). Henceforward Kashgaria remained nominally tributary to China; but though individual emperors asserted their authority in the far west from time to time, the country does not seem to have been regularly organised as a Chinese possession until the reign of the great Emperor Tai-tsong, the first monarch of the T'ang (A.D. 634). Under his equally powerful son Kao-tsong we find Chinese viceroys installed in Turkestan, who entered into regular relations with the peoples of the west. The last Sassanian King of Persia, Yazdijird, communicated with them, demanding Chinese assistance against the conquering warriors

1 "Sand-buried Ruins of Khotan ; Personal Narrative of a Journey of Archrological and Geographical Exploration in Chinese Turkestan." By Price $75.6 d$. net. 